第 3 表（スフ紡）

\begin{tabular}{|c|c|c|c|c|c|c|c|c|c|c|}
\hline \multirow{2}{*}{ 紡出番手 } & 練篠機 & 始 紡 & & & 紡 & & 精 紡 & 機 & $=-\nabla-$ & \multirow{2}{*}{ 備 } \\
\hline & 型 式 & 型 式 & 倍䅗 & 型 & 式 & 倍率 & 型 式 & 倍率 & 有 無 & \\
\hline $20 \sim 42$ & 普 通 & $\begin{array}{l}\text { O K K } \\
\text { D.S } 4 \text { 線 }\end{array}$ & $7 \sim 8$ & & & & D E-K.O & $30 \sim 60$ & ナシ & 筋ローラー1"〜 $1 \frac{1}{8 \prime \prime}$ \\
\hline $60 \sim 80$ & 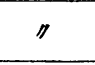 & "I & 5 & $\begin{array}{l}\text { O } \\
\text { D }\end{array}$ & & $3 \sim 4$ & "I & $50 \sim 60$ & "I & "I \\
\hline
\end{tabular}

探用にて補い、棈紡機の「ローラーパーツ」の簡 略化を計りたるもので試驗紡出の結果は至極良好 なるを確認しておりますが、D-S間紡機を省略し た方式も從來の「シムプレツクス「始紡機紡出系よ りも相当可良の紡出をなし得るものであります。 次に「スフ」紡績につんて一言すれば「スフ」
の持つ高度の可紡性は極細系以外は D-S始紡機之 D-E - K型に除電裝置を配したる D-E-K-O型精 紡機の併用は最適の設備となるを確信して止みま せん。又「スフ」の切断長は他纎維との混紡及出 以外にては $1 \%$ 吋長さを最長さすべきでを申し 上げたいと存します。

\title{
紡織技術の水準と本質についで
}

1）・紡熾技衍水準を他の工業のそれと比較し てみることは興味ある問題であると思う。工業の 直接原料は大牛天然資原仙っつてり、天然資榞 とい5ものは世間一般に通用している200扉では 交いが、氣、夜、固体の 3 体に大体区別せられ得 るとして、一体それらを利用する工業の壯態はと らかという問題に帰着する。氣体、夜体を用いる 工業、又は固体でるそれを液体又は氢体に変じて 用いる工業は基礎的の学問体系、理論体系が比較 的現在までとょく出來ていてそれを利用して大体 確実に目的を達することが多いと見られる。例え ば重工業といわれる哭動機はガス体を扱らのであ るが熱力学、流体力学、波動学、化学等によつて 作用現象の根本を知り得るので、理解乃至は技術 の伸長子比較的系統立つて容易に存され得る。例 を挙げれば限りないからててで纎維工業を登場さ せよ5。申すまでも度く繊維は固体である、しか 8他の物質に比して比較的長い分子構造をるつた 特殊店体己以得る。例えばてれを陶磁器工業 の原料である粒度の細い砂と比較してみると同じ 固体であり变がら後者は長さがない、即ち方同性 をもたをいといつた所纎維工業が陶磁器工業よ

\section{会員豊田幸吉 郎**}

り一つの因子だ複雜だしいらてとを知り得る。

2)・しかしながら單に複雜であると申すのみ では技街者の立つ瀨がない、てれを如何にして打 開してゆくかが吾ふ紡織技衍にたづさわる者とし ての行き方があら。全て物事を考える場合は糜 史の流れということを一應参考とするのが常道て あるので、吾くは先づ紡熾技術の歷史を簡單に回 顧してみよう。天然の凟㷧をそのま〉利用すると いうのであるから大昔から存在していたてとは串 実である。それが人間生后の 3 大條件たる衣、食 住の言葉上からは筆頭を承つている衣に関連して いるが故に、余りに身近すきる（確に）上いう点 でそれを利用するのは一体技術がとうかというよ らなことから、明佁中頃よりの近代技衍の與隆時 代から現在までも技衍的には比較的取残されて來 た如き感を呈している。その原因としては第一に 紡織業が庵價販賣主義によつて技術者が殆ん亡全 部之申してもよい位管理者に衣換えしている点、 及び第 1 線の技術者及ひ学者が比較的歷史の新ら しい近代技衍方面に走つた点の 2 つが挙げられ る。しかしはがらてれは敗戰までの統制下の日本 としては技術者として止むを得度かつたか子知れ

* On textıle machinery technique, its level and essentials.

** K Toyoda, Member 株式会普豊田自動織機製作所研究部副部長 
ぬし、この傾向は日本のみならず世界の瀻維工業 を通じてもいい得ることで、即ち瀻維工業は原料 をとのま〉利用するという点で比較的單純度技術 として巷間に放り出されていた憾がある。. 戰爭中 米國及びドイツで、又戰後日本で興隆しつ」ある 化纎はての傾向を打破する第 1 の烽火であつたが その糸の紡織技街という点では矢張り過去の紡織 技術の範囲を余り出ていないーといらょりそれ を利用している—ようである。

以上を概括すれば繊維工業技石は他の近代工業 技術に比して歷史の古い割に発達が遅く低調であ るといい得るの゙である。

3)・そてでその原因となるべき纖維工業技術 面の要素について考えてみると、現在までに繊維 工業技術界でなされた主流の傾向として次の $3 つ$ が挙げられる。

（イ）單緎維の物理性、化学性の追跡研究

(口) 機械の初步的機構の研究

（八）現狀機械を使用しての合理化、能率化 参考までにてれ等がどのように斯界に作用してい るかを述一れば、（イ）は纎維組成を知り得て化 緎等の合成の基礎となると共に瀻維の性質を知り 得るととに役立ち、（口）紡織機メーカーが志 している紡織技術であり、（ハ）は紡織業者が常 に志している紡織技術である、とい5のが現在ま でー否終戰までと申す方かよいかも知れないーの 紡織技術の全般であつた。そして現在もてれ等の 方向は大部分の紡織技衐屋といわれる人が志して いる方向であろ5し、それらの方向には大度る努 力が費されているてとは確なととである。

しかし存がら紡織技衍という見地から見ると上 - 記の 3 方向の他に最も大切な方向が拢けていない かというととである。即ち紡織とは擮維の集合体 を扱う技衍であるというてとで、このてとから緎 維の集合体江対する機械的（電氣的も含めて）作 用ということを考えるべき最も根本の技術研究が 確立されていない。會て東海支部の或会合で日本 毛織彌富の岩田副工場長から“繊維の通る路だけ はアスフアルトにして欲しい”というょうな御注 交をメーカーの者にいわれたが、いい得て妙であ ると思う。
勿論てのてよは多くの技術者の方くが考えられ る点であると思かれるが何故それが盛にならない かが問題で、こてに私が拙文を費したのも実はて のためである。繊維の集合体に人間が右往左往さ せられているのではなく、人間がそれらを上手に コントロールしてゆくのである。てれが取りも直 さ利紡織の本質であると思う。從來もてのてとに 努力がなされながつたかといらと然らずで、(口) 項の機構を考える折も（八）項の能率化合理化を 計る場合も当然出て來たと思われるのであるが、 漠然としていて普遍性あるいわゆる “技獄”にな らず終つたと見ら杂る傾向が多分にある。

何故かとい5反問の前に話を前へもどして固体 の流れ、特に方向性をるつた固体の集合体を取扱 らことは学問的にも比較的難しんことであるとい らてとを想起されるべきである。まして一流の技 迾者、学者が余り立入らなかつた業であるが故 に、その本質の分野において理論体系、学問体系 が出來ていない、又それを確立しようとする傾向 も最近までは余り見られなかつをとい5所に原因 がある。集合体のなす物理、化学現象郎ち紡織現

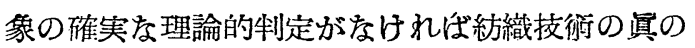
進步は望まれないのである。

4).・それを度すにはど5するかとい5に私は こてに 1つの意見を提して大方の衔批制を得たい のである。先づ前揭（イ）項の物理性、化学性の テストから繊維そのもののの基礎性質を得それをも ととしてその集合体の物性一初步的物性、配列 摩擦、流体的性質、熱関係、静電現象等—との 関連性を求め、分類確定する。その後初めてそれ らら適隼すべき機械作用を定め機構を決定する。 師ち機構等は目的達成の一手段にすぎい。かく して出來て機械はュントロールが理論化されてい。 るので合理化乃至は能率化も非常に樂である。

さてかくいうことは容易であるが繊維工業界特 に紡織技融界としててれを実現さすへく採る方法 はどらかというに、どうしても一流の技䰜者、学 者によらなけ礼ばならない。但一流とは事象の制 定り至は推理が確実で洩れなという意味であ る。紡織現象は現在 1 つの現象に対する棕合的理 論体系てそないが、その現象が幾つの因子によつ 
て成立つているかを判定すればその因子を更に分 割考究するてとによつて、既存の学衍、技衍に帰 して解明せられるものが多、、それに必要疗学乪 技術としては應用物理学、應用数学—郎ち統計 流体、熱、物性、静電等の分野に分れてしまい、 それらを現象と適確に結合して余す所がをいとい らのはどらしても一流の技盛者、学者でなければ ならぬ故である。即ち紡織技盛も近代の原子力時 代に伍してゆくにはどらしても今までの如き偏つ た技術ではなく、綜合技術として学術、技術の一 流の粹を集合すへきであり又それらの意見を徴す るという事のみでる大なる進步を來すであらう。 しかしはがら最も良策としては紡織界が襟度を大 にして技術者の養成機関たる大学、高專に㗢きか け一流技街者の卵を多数同界飞搬入すべきであ る。そして私の述べた紡織現象の䢙の判定及び紡 織技術の確立をなすをぬには、從來の如きいわゆ る紡織学科の範棝:のみで度く前揭した全学街、技 術分野にわたつて意が用いられるべきである。

5 う・所がこてに 1 うの問題がある。技術者の 卵は実際多数存在するが世間一般の全ての物の價 值と同しくピンからキリまであり、一流になり得 るや否や、及び一流に存り得る卵が果して紡織技 。沺に興味をもち得るや否やということである。卵 の生みの親は学者にしてその逆はまあ成立たずと 考えてゆくとて京は一つ、学者に、殊に優秀な学 者に紡織技術方面の興味を持たせることであると いうてとに必然的になうてる。一流の学者に興 味をもたせよ、それには瀻維工業界としてどうす るか? 事は至つて簡單である。紡織技衍の本質が 奈辺にあるかを知らしめ、それが殆んぞ未開の分 野であるてとを知つて革え汭よい。学者に対する
技街委託なども本質にふれたもので或範囲內の技 润者ではどらしても解明し得ねものを、精選して この現象のての部分を、というようにしてなされ るべきだ。

かくする゙てとてよつて次第に氣運が高まつて興 味も持たれるであろらし、未開の現象なるが故に 紡織という專門の講座を持たね所でる 必ずその学 者の自己の講義の中に織込まれて、技術者の卵に 紡織技術も理論的、体系的に出來るものであると いう印象を與えるように度るだろう。そして陸続 と各分野の二流技術者が入り込んで來る特てそ紡 織技衡界、延いては緎維工業界にとつて期待すべ きである。

6 ）・以上新春雜感飞事よせて日頃私の考えて いる小さを所見を書いてみた。文中何故 “一流” という日本語を屡及使用してをたかというと、こ れは 1 つと時代の郎ち歷史の賜である。' 戰後繊維 工業は日本第入の平和產業、輸出產業として大き くクローズアツプされ、質、量共戰前に復帰しよ らと努力せられているが、一方重工業方面特に航 空機工業が禁止せられたてとにより人的にも今ま でになく有利度立場になり得たからである。日本 の同界にとつて世界中でてのように條件の良い國 は極く少数しかないととを銘記さるべきであると 思亏。

最近までの大昔から步一步築いた着実ないわゆ る紡織技衍に加えて前記の開拓がをされいば、ま さに円満に発展すべさ工業として、全ての他の工

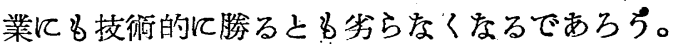
吾々繊維工業にたづさわつている技術者としては その本質の理論化、体系化の方面にも最大の努力 を盡くして後進に道を開くべきであると思5。 